\title{
Acquiring Indonesian for 3-5 Year Olds in the Children Study Group of Wolosoko Village, Wolowaru District, Ende Regency \\ DOI: https://doi.org/10.47175/rielsj.v2i2.258
}

\author{
1,2 Faculty of Teacher Training \\ and Education, Flores \\ University, Argentina \\ Flores University \\ ${ }^{1}$ demomaung05106502@gmail.com \\ 2nikaruing1971@gmail.com
}

| Yosef Demon ${ }^{1}$ | Veronika Genua ${ }^{2}$ |

\begin{abstract}
This study aims to objectively find and describe the acquisition of Indonesian for children aged 3-5 years in the Wolosoko Village Children Study Group, Wolowaru District, Ende Regency (abbreviated as WVCSG). This paper elaborates on the acquisition and the factors that influence the acquisition of Indonesian for children aged 3-5 years at the WVCSG. This research uses a qualitative approach. An approach that emphasizes the originality of the data natural, the researcher acts as a key instrument, the data is collected using the technique of engaging, face-to-face, record and documentation. The data were analyzed using an inductive reasoning model. The theoretical basis of this paper uses Psycholinguistic theory. The results of the study prove that phonologically, children aged 3-5 years are not able to pronounce the sounds [r], [ng], [ny], [y] and [k] perfectly, while children aged 5 years are already able to pronounce these two sounds. perfectly. Morphologically, children aged 3-5 years are able to use basic words and rephrases, while children aged 5 years are able to use three word forms (basic words, rephrases and affix words). Syntactically, children aged 3-5 are able to communicate using 23 words while children aged 5 years are able to use 2-5 words in communicating.

KEYWORDS

acquisition; children's language; acquisition of Indonesian
\end{abstract}

\section{INTRODUCTION}

Language acquisition is the process of humans acquiring the ability to capture, produce, and use lingual units for understanding and communication. This process takes place in the brain of a child when he acquires his first or mother tongue.

Language acquisition is different from language learning. Language acquisition is more directed at the efforts of a child to learn to communicate using the first language or mother tongue. Children have interacted intensively by listening and drill what they hear or say from close people in their family and social environment. Children are always invited to communicate by their parents. Children in this case babies are always treated as if they can speak and understand the meaning of speech.

A child learns to become a member of society through the first language or mother tongue. Mother tongue (first language) is a means for a child to express thoughts, feelings, ideas or hopes. Thus, language is an arbitrary system of spoken symbols used by members of a language community to communicate and interact with each other, based on the culture they share (Dardjowidjojo, 2012: 16).

The ability of children to be able to master their first language within a certain time becomes the concern of language learning experts and psycholinguists. As a baby, the 
child is born crying, then he begins cooing, relatively briefly just the first few years. What a miracle and he was babbling. At that time, it produces sounds that have no clear meaning, which consists of a combination of vowel and non-vowel sounds (Gawen, 2012:5).

Language is the most effective collaborative tool and communication in interacting. Thus language has an important role in everyday life. The role of language must be understood as a practical form of using the language in various spheres of life by adhering to the principles of good and correct language.

As adult humans in general, children also have a vocabulary of experience and knowledge that drives their activities in responding to themselves with the outside world. World treasury and knowledge that reduce children's activities have different characteristics according to the age level and the environmental conditions that make them up, (Gawen, 2012: 54).

Language, apart from being an element of culture, enables humans to take advantage of experience. Their experiences, learn about and partake of those experiences, and walk with others. Language is also a system that uses vowel symbols (speech sounds) that are arbitrary, which can be strengthened by real physical movements (Keraf, 2004:6).

There are many stages of language development that must be passed and of course with a lot of practice and experience, and most importantly how the environment plays a role in providing support and stimulation as children, so that they are this good. The way language changes and gives rise to new varieties is not something new (Bernal et al, 2021: 416).

Children's language development can be grouped through stages, namely the semantic stage and grammatical relationships. At this stage two words appear. The next stage appears clearer words and sentences and the next stage, more abstract sentences.

The Wolosoko Village Children Study Group (WVCSG) is one of the early childhood learning groups located in Wolosoko Village, Wolowaru District, Ende Regency. This village community is a mnonolingual community which means a community that only uses one language for daily communication. Apart from the regional language backgrounds, the social, economic and educational backgrounds of parents are very diverse. The diversity of the backgrounds of the members of this community sparked the intention to immortalize oneself through this simple study. This simple study is expected to be able to reveal the phenomenon of children's language acquisition and the factors that support and hinder children's language acquisition.

\section{RESEARCH METHODS}

Data were collected using blanded methods or mixed methods. Direct observation of children's communication activities, listening, chatting (Ridwan, 2004: 104), recording and documenting the research data. The research is concentrated on WVCSG aged 3-5 years in Wolosoko Village, Wolowaru District, Ende Regency. Data were analyzed using inductive-deductive or deductive-inductive reasoning models. The study was conducted in a university in the Philippines. It is a research driven university and currently celebrating its centennial year of existence and was considered as one of the pioneering universities in the reasoning models.

\section{RESULTS AND DISCUSSION}

The findings of this study refer to the research problem, namely the acquisition process and the factors that affect children's language acquisition. Three year olds are familiar with vowels such as, [a], [i], [u], [e], [o] and the vowel sequence [au] as in the words 'wau, lau, 
kau, and others'. Vowel sounds are a type of language sound that is produced after the flow of words out of the glottis does not face obstacles from the speech apparatus, but is only disturbed by the position of the tongue, both vertical and horizontal and the shape of the mouth (Chaer, 2009: 38). Meanwhile, consonants are language sounds that are produced after the flow of words leaves the glottis, encountering obstacles to certain speech tools in the oral cavity or nasal cavity (Chaer, 2009: 48). There are consonants that have been mastered by children such as, [b], [d], [m], [n], [t], [p] and [s]. Children aged 3-4 years are not able to pronounce sounds $[\mathrm{r}],[\mathrm{y}],[\mathrm{ng}]$ and sounds $[\mathrm{k}]$. The inability to pronounce the sound $[\mathrm{r}]$ is the cause of replacing sound [r] with sound [1], sound [k] is replaced with sound $[\mathrm{t}]$, sound $[\mathrm{ng}]$ is replaced with sound [n] and sound [y] is replaced with sound [1 ]. The replacement of sound [r] with sound [1] and sound [k] with sound [t], sound [ng] with sound [n] and sound [y] with sound [1] is based on phonological similarities and differences. Sound [ng] and sound [n] are different articulation (touch purpose) but articulator (motion device), sound [y] and sound [1] are two different sounds in terms of motion and touch purpose but both have distinctive characteristics which the same that is both consonantal. The sound [1] will dominate the sound [y] because the sound [y] is a voiceless. Sound [r] and sound [1] are two sounds that are articulated differently, sound [r] is a vibrating sound and a sound [1] is a lateral sound. Articulatively the [r] and [1] sounds are apicoalveolar sounds. The sound [k] and sound [t] are two different articulatory sounds, the sound $[\mathrm{k}]$ is a velar sound and the sound $[\mathrm{t}]$ is an apicointerdental sound. In articulation, these two sounds are the same as sound inhibition (Santoso, et al., 2017: 43; Clark, 2009: 50) Children aged 5 years are able to pronounce the sounds [r], [ng], [y] and [k] with right.

Children aged 3 and 4 years have a vocabulary that includes basic and derivative words. This means that children aged 3 and 4 years have adequate basic vocabulary to communicate. Children 3 and 4 years of age do not yet have lingual units with an affix. Children 3 and 4 years of age have used nouns and verbs in a very limited scope. Thus the lexicon used is the basic lexicon. Children aged 5 years already have a number of lexicons that are adequate and varied. Mastered word categories such as nouns, verbs, adjectives and adverbs (Dari, 2020: 41). Children aged 5 years have basic vocabulary and have affixes.

Syntactically, children aged 3 and 4 years have not been able to use affixed lingual units. Children 3 and 4 years of age are only able to use basic lingual units. Syntactically, children aged 3 and 4 years are able to make sentences using 1 base unit, two base units and / or three and four base units. The sentences that are produced are very simple. This can be seen in the basic units used such as nouns and verbs. A 5 year old child has a sufficient number of vocabulary to produce simple, complete sentences. What is meant by complete is the completeness of the core elements or the completeness of the syntactic function such as subject, predicate, object and even description. The area of the children's interaction is wider so that it affects the productivity of increasingly varied sentences.

\section{Discussion}

Early childhood language acquisition is a compilation of a number of physical psychic developments such as psychology, neurology, mental, linguistics, cognitive, and others. In connection with the acquisition of language for children aged 3-5 in WVCSG for children aged 3-5 years, there are a number of theoretical bases such as Behavioristic Language Acquisition, Mentalistic Acquisition and Cognitive Language. The application of these three theoretical foundations is expected to be able to obtain better and useful studies (Chaer, 2009: 25). Thus the acquisition of language for children aged 3-5 years at WVCSG is not seen as a linguistic development only but also as a development of language 
behavior, neuro development, mental development of language, philosophy, primatology and genetics (Dardjowidjojo, 2012: 6). The acquisition of children's language is a combination of a number of disciplines such as linguistics, psychology, psycholinguistics, sociolinguistics, and social psychology (Troike, 2006: 3-4).

The language acquisition aspect states that the child born is considered to be empty of language. Psychologists argue that a child born does not carry the capacity or potential for language. A child who is born into this world is like a white cloth without defects, the environment is what gradually shapes his language behavior. With regard to language acquisition, behaviorist theory bases the acquisition process through changes in observed behavior. Behavioristic ideas are based on learning theory that focuses on the role of the environment, both verbal and nonverbal. For behaviorists, language is the whole basic human behavior that develops from birth.

Mentalists or rationalists or nativists argue that the language acquisition process is not due to the result of the learning process, but because from birth the child has a number of language capacities or potentials that will develop according to their intellectual maturity ${ }^{\mathbf{1 0}}$. Language acquisition at each stage is a systemic stage, in the form of innate completeness coupled with the child's experience when he carries out self-socialization. These innate features are expanded, expanded, and even changed.

Cognitive theorists claim that mentalists 'opinions are very abstract, formal, and explicit and very logical ${ }^{11}$. The new mentalists put forward explicitly the forms of language and have not yet concerned the deepest layers of language, namely memories, perceptions, thoughts, meanings, and emotions which influence each other in the structure of the human soul. Cognitive theory emphasizes mental work outcomes that are thought to be qualitatively different from observable behavior. The starting point of cognitive theory is the assumption of a child's cognitive capacity to find structures in the language he hears around him.

Dardjowidjojo (2012) explains that a child at the age of 6 months has started to make consonant or vowel sounds. The shape of the sounds cannot be ascertained because the shape is not clear. In the two-word sentence period, a child has started to make a sentence consisting of two words. In the field of syntax, children begin to speak by saying one word or part of a word (Indah, 2008:104).

Referring to the findings about the process and factors that influence language acquisition of children aged 3-5 years, the following will be presented with a discussion of the findings.

\section{Development in the Field of Phonology, Morphology, and Syntax for Children Aged 3 Years}

Three year olds have mastered all vowel phonemes. However, there is an interesting phenomenon, namely sound jumping. The lateral sound [1] which is at the end of the first syllabary is replaced by a hissing sound [s] which is in the starting position of the second syllable. This phenomenon as seen in the example of balsam is pronounced baslem. This phenomenon of sound jumping certainly has a strong phonological basis in connection with the child's regional language sound system. The following will provide an example of the phonological field in language acquisition for children aged 3 years.

Example (1)

Dewi matan

'Dewi makan'

'Dewi eats' 
Example (1) states that a 3 year old child pronounces the dorsovelar sound $[\mathrm{k}]$ in the word eat with the sound apicointerdental $[\mathrm{t}]$ matan. The sound $[\mathrm{k}]$ and the sound $[\mathrm{t}]$ are two sounds that are different in terms of motion but have similarities in the purpose of touch. The sounds $[\mathrm{k}]$ and $[\mathrm{t}]$ are voiceless popping inhibitory consonants. It is this similarity that triggers the sound $[\mathrm{k}]$ to be pronounced $[\mathrm{t}]$. Apart from that, the incompleteness of the speech tools and difficulty in pronouncing it are obstacles outside the language. The phenomenon of pronouncing the sound $[\mathrm{k}]$ with the sound $[\mathrm{t}]$ can also be noticed in the following example 2 .

Example (2)

Meleka matan itan

'Mereka makan ikan'

'They eat fish'

Examples (1) and (2) state that the pronunciation of such a sound applies to the glotal sound $[\mathrm{k}]$ in all positions, both initial and middle. Apart from pronouncing the sound $[\mathrm{k}]$ with the sound [t], children aged 3 years also pronounce the sound [ng] with the sound [n] as shown in the following example (3).

Example (3)

Kau janan matan

'Kau jangan makan'

'You don't eat'

Example (3) illustrates how the child has difficulty pronouncing the sound [ng]. Based on the air outlet the sound [ng] is a nasal sound, the same as the sounds [m], [n] and [ny]. Based on the tools of motion [m] and [n] are bilabial and interdental sounds. These two sounds are easier to pronounce because of the elasticity of the child's tongue. The sound [ng] and sound [ny] have a very complicated level of difficulty that makes the child unable to pronounce them. This complication is due to the movement of the middle of the tongue (lamino) which has to touch the soft palate (palatum) for the [ny] sound and the back of the tongue (dorsum) rising towards the back of the palate (velum) for the [ng] sound. The level of complexity of the pronunciation is what causes the sound [ny] and sound [ng] to be pronounced with an interdental sound [n]. Does the sound [ny] and sound [ng] have the same phonological characteristics as the sound [n]? Both are consonantal, nasal and voiced, what distinguishes them is that the sound [n] is interdental, the sound [ny] is laminopalatal and the sound [ng] is a dorsovelar sound.

The following will present data on the morphological development of children aged 3 years.

Example (4)

Lumah sala besal

'Rumah saya besar'

'My house is big'

Example (5)

Bapa tidul

'Bapa tidur'

'Father sleeps'

Examples (4) and (5) illustrate that the child is unable to pronounce the apicoalveolar [r] sound and palatal sound. This sound [r] is pronounced with a lateral sound [1]. Both of these sounds make use of the apex as a means of movement while the purpose of the touch is different. So on the one hand these two sounds are the same in some respects and different in another. In articulation, the sound [r] is vibrating while the sound [1] is lateral. Nonetheless, both of these sounds are voiced apicoalveolar. The palatal sound [y] is also 
unpronounceable for children aged 3-4 years. The sound [y] is replaced by the sound [1]. These two sounds are different based on both the motion device and the touch purpose. The sound [1] is the audible lateral sound dominating the unvoiced sound of the palate. Although they are different, these two sounds have the same distinctive feature, namely that they are both consonantal. The factors that influence this phenomenon are the completeness of the 3 year old child's speech apparatus and the difficulty level of pronunciation. In other words, the inability to pronounce affects the ability to pronounce. Linguistic limitations, such as the completeness of speech instruments, also affect the use of sounds. The production of lingual units is still very limited to certain forms and categories of words. The morphological abilities of children can be observed in the following data.

Example (6)

Andi ail

'Andi air'

'Andi tolong ambilkan saya air'

'Andi, please get me some water'

The child wants to express his desire to someone (Andi) to take or give him drinking water'. There appears to be complexity and difficulty in syntax while the vocabulary is very limited so that the child only expresses the solid idea in two words or two basic units. There is a phenomenon of omiting predicate verbs with the affix 'berikan, ambilkan' in example (6).

Example (7)

Saya tida main

Saya tidak bermain

'Saya tidak ingin/mau bermain'

'I don't want to play'

Example (7) indicates that morphologically, children aged three years do not have vocabulary with affixes. There is an imprint of the prefix ber-on the sentence's predicate. The child wants to say 'I don't want / want to (play)'. Apart from not having adequate affixed vocabulary, the child's first language background plays a very important role in this. Data (6) and (7) indicate that children often express their desires by utilizing basic lingual units or basic morphemes because of the limited vocabulary of affixed units.

Example (8)

Mari

'Mari'

'(Ke)Mari'

'Come here!'

Example (8) reveals the ability of a three year old child to syntax using one basic lingual unit 'Mari'. The complexity of the idea to be conveyed, while the lexicon vocabulary is very limited so that the child only chooses one basic core unit, namely the predicate 'Mari. The child's first language background plays an important role in the formation of children's basic sentences.

Example (9)

Bapa cali tayu

'Bapa cari kayu'

'Bapak mencari kayu'

'Father looking for wood'

Example (9) states that 3 year olds are syntactically able to make simple sentences using one or three basic units. Example (9) illustrates the child expressing desires using three 
basic lingual units. Example (1-9) states that the acquisition of speech sounds, basic lingual units and basic sentence units is not yet perfect.

\section{Development in the field of Phonology, Morphology, and Syntax of 4 Years Old}

Four-year-olds showed a slightly different development of sound, word form and sentence structure compared to three-year-olds. The development of the three linguistic aspects in this four year old child can be observed in the following description.

At the age of four, the child has mastered all vowel phonemes, but there are words that are not pronounced correctly, for example dirty is pronounced dirty, close is pronounced beating and eating is spoken. The acquisition of phonology in children aged four years is as follows:

Example (10)

Lumah tami ada anjing

'Rumah kami ada anjing'

'Our house has dogs'

Children still have difficulty pronouncing the sounds $[\mathrm{r}]$ and $[\mathrm{k}]$. The sound $[\mathrm{r}]$ is still pronounced with [1] and the sound [k] is pronounced [t]. Although articulating the sounds [r] and [1] are different, articultically, these two phonemes are both apicoalveolar and voiceless. Likewise, the sounds $[\mathrm{k}]$ and $[\mathrm{t}]$ are the same articulation that is inhibitory but articulatively the phonemes $[\mathrm{k}]$ and $[\mathrm{t}]$ are different, $[\mathrm{k}]$ dorsovelar sounds while $[\mathrm{t}]$ are apicoalveolar. The complexity of the utterances due to the limited completeness of the utterances is a contributing factor. In addition, non-language factors such as the development of children aged 3 and 4 years are very close together so that the development of sound systems in children aged 4 does not appear to have a significant difference.

The aspect of acquiring tenses has progressed, such as the use of affixed lingual units. The progress in using affixed lingual units can be noted in the following data.

Example (11)

Kemalin kami belenang di tali

'Kemarin kami berenang di sungai'

'We swam in the river yesterday'

Exampel (11) describes the vocabulary breadth of children aged 4. The juxtaposition of a number of lingual units in forming a simple sentence. Children have started to use lingual units with affixes for example in the word swim 'belenang'. Examples (10) and (11) show affix embedding.

Example (12)

Meleka tidak ada di lumah

'Mereka tidak ada di rumah'

'They're not at home'

Example (12) proves that the presence of affix ber-is dependent on the predicate of being human. In contrast, affixes in example (11) are mandatory. If so then semantically the meaning of these two lingual forms is different. This means that affixes which are obligatory in nature have different meanings from affixes which are not obligatory.

Example (13)

Om cali lumput

'Om mencari lumput'

'Uncel looking for grasss'

Example (13) also indicates a morphological and semantic similarity. There is a perforation of the affix me- to the predicate cali verb 'seek'. Example (10-13) reveals that morphologically, a 4 year old child has sufficient lexicon vocabulary for children his age. 
There is a phenomenon of penetration and use of affixes based on mandatory and nonobligatory aspects.

Increasing the age of the child also adds to the lexicon vocabulary that is mastered by the child. Children aged 4 years do not show a significant development in the acquisition of sound systems, but in the aspect of word form and sentence structure, they show a significant development. The development of children's sentence structure at 4 years of age can be considered in the following explanation.

Example (14)

Bibi tida tidul di sini

'Bibi tidak tidur di sini'

'Aunti does not sleep here'

The use of basic lingual units is increasing rapidly. If at the age of three the child needs one or two lingual units to express his opinion, then at the age of four the child uses more than three basic units to express his wish. In general, it can be said that at the age of 3 years the child uses one or two basic units as the basic material for sentences. One or two basic units are the core elements of the sentence, both the function of the subject, predicate and object.

\section{Development in the Field of Phonology, Morphology, and Syntax of 5 Years Old}

The physical development of children aged 5 years has progressed quite rapidly. This physical development was accompanied by the development of the use of speech instruments so that the pronunciation of the sounds of the mother tongue and the second language was quite perfect. Children aged 5 years are able to pronounce complex sounds such as $[\mathrm{r}],[\mathrm{k}],[\mathrm{ng}],[\mathrm{y}]$ and [ny] while in regional languages complex clusters such as [nd], [ng], [ngg], [mb], [dh], [bh], and [gh] can't be pronounced correctly.

The development of the morphological aspects of children aged 5 years shows an increasing number of lexicon vocabulary, both basic and derivative. The child has been able to use more of the basic units in line to express their thoughts, as shown in the following data.

Example (15)

\begin{tabular}{|l|l|l|}
\hline a. & Kami tida ada minyak goreng & We don't have cooking oil \\
\hline b. & Mama bilang tunggu sebentar & Mom said 'wait a moment' \\
\hline c. & Mereka mama di rumah & Mom is in the house \\
\hline d. & Besok pagi om pergi & Uncle will go tomorrow \\
\hline
\end{tabular}

The syntactic development of children aged 5 years is growing rapidly. The resulting simple sentences use a larger number of base units. The resulting simple sentences are complete simple sentence forms. This means that children can include the core elements of sentences such as objects and descriptions. The sentences used by 5 year olds can be seen in the following data.

Example (16)

\begin{tabular}{|l|l|l|}
\hline a. & Bapak beli bola di pasar & Father bought a ball in the market \\
\hline b. & Mama cari sayur di kebun & Mom is looking for vegetables in the garden \\
\hline c. & Seтиa guru ada rapat & All teachers have meeting \\
\hline
\end{tabular}

Example (15) illustrates that the syntactic ability of a 5 year old child is adequate. The presence of syntactic functions in the sentences indicates that the child is very aware of the presence of syntactic functions such as objects that are needed by the verb predicate of the sentence as seen in the verb predicate of beli and cari. Even though they do not understand 
well about verb valence, children have proven that the presence of other elements is very important for the completeness of a sentence.

The physical and psychological development of children indicates perfection in pronouncing word sounds, the ability to utilize lingual units both basic and derivative and the ability to form increasingly complete simple sentences.

\section{CONCLUSION}

Universally, not all languages have identical rules. There are differences in sound system systems, differences in word categories, basic differences in word order, differences in speech acts and differences in meaning (Clark, 2009:4). This difference is also experienced by children aged 3-5 years at WVCSG. A study of the discussion proves that phonologically, children aged 3 and 4 years are not yet able to pronounce the sound [r] and sound $[\mathrm{k}]$. Sound [r] is often pronounced with sound [1], sound [ng] is pronounced with sound $[\mathrm{n}]$, sound $[\mathrm{y}]$ is pronounced with sound [1] and sound $[\mathrm{k}]$ is pronounced sound $[\mathrm{t}]$. This sound replacement is based on a phonological basis. The sound [r] and [1] are two sounds that are articulated differently but articulatively the sounds [r] and [1] are apicoalveolar sounds. Sounds [ng], [ny] and sound [n] are sounds that are articulators different, while articulating sounds [ng], [ny] and sound] n] are voiced nasal. The sound [y] is a laminopalatal sound pronounced with a lateral [1] sound. These two sounds differ in articulatory and articulate terms but have the same distinctive characteristics, namely syllabic and sonorant. Likewise, the sound $[\mathrm{k}]$ and the sound $[\mathrm{t}]$ are two sounds that are the same articulation, namely the inhibiting sound, while articulatively the sound $[\mathrm{k}]$ is a dorsovelar sound and the sound [ $\mathrm{t}$ ] is an apicoalveolar sound. Children aged 5 years have demonstrated the ability to pronounce $[\mathrm{r}]$, [ng], [ny], $[\mathrm{y}]$ and $[\mathrm{k}]$ well. The factors that underlie the difficulty in pronouncing the sounds [r], [ng], [ny], [y] and [k] are the complexity of the sounds and the incomplete radiant speech tools (motion tools and touch purpose). Ages 3 and 4 years are coincidental, so the development of sound systems is not as fast as children aged 5 years.

Children aged 3 and 4 have a limited vocabulary. Mastered word categories such as nouns and verbs are often used in communication. The lingual units most commonly used by 3 and 4 year olds are nouns and verbs. Children aged 3 and 4 years do not have an affixed vocabulary, so it is very rare for children to use words with an affix. In contrast to children aged 3 and 4 years, children aged 5 years have an adequate number of vocabulary. The word categories used are also increasingly varied, such as nouns, verbs, adjectives and adverbs. The power of the social area causes the child to have a number of affixed vocabulary.

Syntactically, children aged 3 and 4 years are only able to produce simple sentences with a number of lingual units of 1-3 words and the most frequently used word categories are nouns and verbs. Units consisting of 1 word are not interpreted as words but are interpreted as a minimal sentence, minor sentences or incomplete sentences. This is understandable because of the complexity of the ideas to be conveyed, while children's vocabulary is very limited. Units consisting of 2-3 are also not interpreted as phrases but are interpreted as minimal sentences or minor or incomplete sentences. These units are the core units that represent the child's intentions. Children as young as 5 years old already have a large number of vocabulary words and a variety of word categories allows children to produce simple, complete sentences. What is meant by complete is the completeness of the core elements or the completeness of syntactic functions such as subject, predicate, object and description. The child has realized the presence of the object function of a sentence because of the demands of the verb predicate. 


\section{REFERENCES}

Bernal Jr., H. L., Gumaru, R. C. R., \& Oleo, S. T. (2020). Filipino As Second Language: Guide In Acquiring Filipino By Reading Novels. Randwick International of Education and Linguistics Science Journal, 1(3), 416-422.

Chaer, Abdul. (2009). Fonologi Bahasa Indonesia. Jakarta: Rineka Cipta.

Clark, Eve. E.(2009). First Language Acquisition. Second Edition. United States of America: Cambridge University

Dardjowidjojo, Soenjono. (2012). Psikolinguistik: Pengantar Pemahaman Bahasa Manusia. Jakarta:Yayasan Pustaka Obor Indonesia

Gawen, Alexander Bala. (2012). Pemerolehan dan Pembelajaran Bahasa. Ende: Nusa Indah.

http: //www.google.com//amp/s/www.kompasiana.com

http://yosiabdiantindaon.blog.spot.com/2012/05/teori-akuisisi-bahasa

Indah, Rohmani, dan Abdurrahman. (2008). Psikolinguistik. Malang: UIN-Malang Press

Keraf, Gorys. (2004). Komposisi Ende. Nusa Indah

Dari, Mariana Vivian Eka. (2020). Pemerolehan Bahasa Indonesia Anak Usia 4-6 Tahun Pada PAUD St. Alexandria Desa Magekapa, Kacamatan Maukaro, Kabupaten Ende (Skripsi). Program Studi Pendidikan bahasa dan Sastra Indonesia, Fakultas Keguruan dan Ilmu Pendidikan Universitas Flores

Ridwan. (2004). Belajar Mudah Penelitian untuk Guru-Karyawan dan Peneliti Pemula. Bandung: Alfabeta

Santoso, Singgih, dkk. (2017). Menguasai Statistik Dengan SPSS 24. Jakarta: PT Elex Media Komputindo

Troike, Muriel Saville. (2006). Introduction Second Language. United Stated of America: Cambridge University Press 